Article

\title{
Nubia Still Exists: On the Utility of the Nostalgic Space
}

\author{
Menna Agha \\ Faculty of Design Science, University of Antwerp, 2000 Antwerpen, Belgium; Menatalla.Ahmed@uantwerpen.be \\ Received: 27 November 2018; Accepted: 24 January 2019; Published: 31 January 2019

\begin{abstract}
The Egyptian government displaced all Nubian villages to build the High Dam. New generations of Egyptian Nubians still identify as displaced and live in a nostalgic virtual space that carries a rendition of a paradise-like old Nubia. I investigate this spatial phenomenon by surveying Nubian literary and oral tradition, which displays signs of belonging to a geography that is no longer material. This paper lays out a conceptualisation of this space of nostalgia perpetuated in a metanarrative of a utopian lost land, that poses it as a disembodied territory while nostalgia is territoriality. From my position as a Nubian woman and a scholar, I use auto-ethnographic tools to methodically decode and layout this territory. The paper offers empirical evidence of the effect of these virtual territories on materialised spatial production and, therefore, argues that Nubians remain space makers by carving their own virtual territory and that Nubia still exists.
\end{abstract}

Keywords: Nubia; nostalgic spaces; displacement; territory; disembodied territoriality; spatial production

\section{Introduction}

Nubia in an ancient land that extends between the first and fifth cataracts of the Nile river, in the area now divided between Egypt and Sudan (Kirwan 1974). The name Nubia has been open to different scholarly interpretations. Hillelson (1930, p. 142) says that the word comes from Nebed, an inscription of Egyptian king Thutmose I (ca. 1450 B.C.) referring to the people with curly hair whom he invaded. Arkell (1961, p. 177) states that the word is derived from a Nubian word meaning 'slave'. This research, however, acknowledges the conventionally used meaning among Nubians, which derives the term Nubia from the Nubian word nubere meaning 'gold', making Nubia the Land of Gold. Despite contested etymology, Nubians have the right to appropriate or explain the name of their own homeland.

Nubians territorialised the banks of the Nile river for millennia, during which many population movements happened from and to the Nile valley, thus rendering a clear and singular genealogical identification of Nubians very difficult. However, today, the term 'Nubians' usually refers to Nubian groups in Egypt and Sudan, in addition to a sizable community in Kenya, who arrived during the 1890s as soldiers in the British army (Duncan 2013). The area that is now separated between Egypt and Sudan was once united until the British colonisers drew the line separating it in 1899 Likewise, in 1956, the area was divided, separating the Nubian Land, separating the Nubian Land (Abushouk 2010), and the separation split the Nubian village of Adendan between postcolonial Egypt and a Sudan under British rule.

In the 1960s, the Egyptian postcolonial state started building its national megaproject, the Aswan High Dam, with the promise of introducing Egypt to industrialised prosperity. The dam, however, claimed Nubians and their land as victims; its water reservoir submerged the entirety of the Nubian territory within the Egyptian borders and parts of the Nubian land in Sudan (Dafalla 1975). The dam displaced 50,000 Nubian families (Fernea 1963). The Egyptian government built a large housing project 
in the Kom-Ombo Valley to resettle the Nubians; the planning was premised as an effort to bring the 'Marginal Nubians' to the mainstream of Egyptian society (Nasser 1960) and, therefore, modernise this African peoplehood.

This paper looks specifically at the case of Nubians in Egypt and the ways in which They reclaim their territory. While Nubians in Sudan and Egypt share their language, dialects, hardship, and blood kinships, the two groups also now share a popular culture, with songs and artists crossing the border, making their popular culture closer to one another than to the rest of Egypt and Sudan. The decades of separation in political economic and geographic circumstances made it impossible for the Nubian communities in Egypt and Sudan to maintain the same characteristics, which makes it difficult for this research and most of the contemporary research on Nubians to bundle Sudanese and Egyptian Nubians as a singular group with a shared experience.

Nubians in Egypt can be categorised into two main groups: Fadidja (pronounced Fadidcha), and Kenouz (or Mattoka in fadidja's language). Another group that could be placed under the category Nubians are 'Aswan Arabs', referring to Arabic-speaking groups, in particular, of the non-Nubian villages displaced by the High Dam, whose inclusion in Nubian culture and networks is now built on political interest, solidarity, and shared struggles. All together, there were forty districts displaced by the High Dam, of which seventeen were Kenouz, five were Arabic-speaking, and eighteen were Fadidja, according to the language spoken (Hopkins and Mehanna 2011, p. 10)

Nubians suffered an affective and material disenfranchisement throughout the process of their displacement, a recurrent effect on those affected by Development-Induced Displacement and Resettlement (DIDR) schemes around the world (Cernea 1996). The state-built resettlement villages, formally named 'New Nubia', did not fulfil the promise of the 'good life'. The housing project was hastily built, and its architecture was 'unimaginative' (Serageldin 1982). Nubians refused to call these settlements New Nubia and instead called it Tahgeer, meaning place of displacement.

The High Dam was not the Nubians' first displacement; the Aswan Low Dam preceded it. The Aswan Low Dam, which was constructed on the Nile's first cataract by British colonialists in 1902, and was subsequently heightened twice-in 1912 and 1933 (Waterbury 1979). The Low Dam was the cause of grave loss and agony for Nubians, as it caused the water levels behind it to rise significantly and devastate Nubian crops and houses. Nubian author 'Ezz-Eldeen Sakoury' documented the stories of his mother and the women of her generation in a Manuscript of an unpublished book. ${ }^{1}$ The book contains tragic stories about the water coming to Nubian houses at night, drowning sleeping people and causing a disturbance in the ecosystem.

Predicting that Nubians would join the fabric of the Egyptian culture and assimilate, the Egyptian state expected Nubians to adopt a 'modern Egyptian' identity without their ancestral land. Nubians kept the image of their old land alive in their memory, along with their grief, sorrow, and yearning for a lost paradise. Today, after a half century of displacement, Nubians still identify as Nubians first, while new generations of Egyptian Nubians-like myself-still call their settlements Tahgeer. Moreover, those who never saw their old land-like myself-still identify as displaced and are nostalgic for their old land, even though it was completely submerged when they were born; they became displaced from a place they had never been. To this day, Nubians are actively working towards a return to their homeland (Janmyr 2016), or more accurately, to an offset of this land on the shores of the High Dam reservoir.

After completion of the involuntary resettlement and the submergence of the Nubian land, the international academic consensus, especially among archaeologists who perceived the Nubian land as an incubator of monuments from an ancient civilisation, was that Nubia was no more and was now 'lost' (Fernea 1963; Horton 1964; Emery 1967; Bell 2009; Scudder 2016). To them, the land once called Nubia and the origin of that long history would only be an archived memory and a space of the past.

1 I found the Manuscript of this untitled book among the belongings of Ezz-Eldeen Sakoury in his house in Qustul, Aswan. 
The difference here between the perception of loss for Nubians and scholars is vivid. To Nubians, the paradise, but not Nubia itself, was lost. Nubians refuse to acknowledge the New Nubia but also refuse to acknowledge the vanishing of Nubia as long as as long as they are alive.

Methodologically, I apply positionality, reflexivity, and relationality. I conduct research from my position both as a Nubian and a scholar. As a Nubian woman, I have insider access to the site of investigation, which is the collective imagination of my people. To say that one is an insider raises the question 'What is it that an insider is inside of?' (Merriam et al. 2001). Most cultures have subcultures, and subcultures have other sub-subcultures, but in the case of the Nubian society, the landless state of Nubia has driven Nubians to draw clear cultural borders between what is Nubian and what is not. The borders contradict the state narrative that the Egyptian population is all 'one'. A Nubian knows precisely the difference between being Egyptian and being Nubian. With this phenomenon in place, I can claim that the research for this article comes from an insider's perspective within this imagined border.

In this research, I situate myself on the Nubian side of the story, as, Donna Haraway argues, one is always on a side of the story, as all knowledge is situated knowledge (Haraway 1988). Also, I cite standpoint theory to argue against the common assumption that political interest damages scientific production (Harding 2004); rather, a standpoint of dispossession can induce the production of new theories due to the pressing need to understand its contemporary phenomena. My position entails many tensions between my desire to understand the happenings of my context and to advance the Nubian cause and my institutional aspirations as a scholar in a European research institution. Therefore, I have committed myself to methodological reflexivity (Pini 2004), by which I mark my bias and sovereignty throughout my research activity.

The research method depends on Boym's (2008) argument regarding nostalgia's spatial nature. She claims 'nostalgia is spatial in its expressions as well as causes' (xviii) and proposes a dual-spatial archaeology as a methodic tool to investigate nostalgic expression: 'Nostalgia should be investigated using "dual archaeology of memory and place, and a dual history of illusions and actual places"'. This research employs Boym's method in investigating the Nubian space in nostalgic expressions of Nubian cultures, for example, images of old Nubia in oral history after displacement and descriptions of the lost land in modern and contemporary literary production. Moreover, the research conducts an analysis of current spaces produced and occupied by Nubians after displacement. This research finds that the nostalgic expression has oozed into materialisation, thus affecting, appropriating, and reforming the spaces of displacement and diaspora.

\section{Who Defines Nubia?}

To be able to justify the claim that Nubia still exists, it is imperative to venture into the different definitions of 'Nubia' itself; it is also essential to question the mechanisms of production for each of these definitions. The submergence of the historical land's material evidence has moved the narratives about Nubia into a space of remembrance, rendering nostalgia-or different forms of nostalgia-as the main operational tool in reproducing the idea of this lost land. Understanding the definition of Nubia in these different forms of nostalgia requires positioning their initiators in time and space, as space and time from which people evoke nostalgia are as important as the space and time nostalgia evokes (Hui 2013). This renders the act of defining Nubia within nostalgic narratives contingent on what the narrator's political interest requires from 'Nubia', or needs it to be.

For instance, academics in Nubian studies had developed an image of Nubia that stems from nostalgia-a colonial nostalgia about a space they saw from a boat in the Nile (Gregory 2001). A visual centred around ancient stone temples, with Nubian people and their houses often serving as their background, came to be the dominant image of Nubian space and eventually defined Nubia in the literature of the early twentieth century. Those who had the power to publish, document, and disseminate their nostalgic images sailed through Nubia and proposed an image of a Nubia with a 
glorious past of kings and queens—a romantic Gloriana (Mazrui 2005)—hence, producing a spatial definition of Nubia only through historicisation.

Such an image extends from Egyptology and the colonial interest in the powerful pharaohs, while Nubians and their peoplehood stood in the periphery of these images. The knowledge production of the nostalgic image translated into materiality during the 1960s in what was known as the Rescue Nubia Campaign (Hassan 2007), an international effort led by the academic community and spearheaded by the United Nations Educational, Scientific, and Cultural Organization (UNESCO). The campaign raised funds and successfully saved numerous archaeological sites with minimal regard to the Nubian people, their culture, and everyday architecture. This is evident in Walter Emery's book Lost Land Emerges (1967), in which he describes the rescue campaign. The lost land, to Emery, was the land of ancient stones, and its emergence was the emergence of stone, as Nubian, to the members of the rescue campaign, had only existed as historiography.

To Nubians, the unspoken differentiation between the lost paradise and the lost Nubia is vivid. Narratives of loss exist simultaneously with a denial that Nubia ceases to exist. The Nubia that exists, in this case, is also produced through nostalgia. Nevertheless, nostalgia here is a form of emotional labour. Nostalgia, to Nubians, is an implicit social duty as well as a common denominator; it is an amalgam of emotional resources, such as pain, sorrow, and yearning for somewhere other than the 'here', juxtaposed over an image coded in their collective conscious. To Nubians, Nubia can be described as collective virtual spatialities fuelled by nostalgia and disembodied from its materiality.

These narratives were incubated and reproduced through Nubian affective resources. Our grandmothers' stories were always present to describe spatialities of the old land. Nubian literature and poetry are exceptionally descriptive in drawing an elaborate image of a land that is now under water. They create not only an abstract image of a place but also a dynamic depiction of everyday life that has been collectively adopted by Nubians to maintain such peoplehood. The cradle of the nostalgia for the old land, however, is in the circles of the elderly Nubian women. Nubian women are trained and conditioned to narrate, as their gender role has included the tasks of storytelling since before the age of television and modern entertainment.

\section{Nubian Nostalgic Expressions}

Before delving into an exploration of Nubian nostalgic narratives, it is vital to introduce languages, as they mediate these expressions. The Nubian language belongs to the Nilo-Saharan phylum, and it is the only language within this phylum that can be traced back over a thousand years (Bechhaus-Gerst 2011). Reference to the Nubian language throughout this research refers to Nobiin, the most recent variation of the language. The Nubian language spoken in Egypt can be divided into Fadedji and Kenzi, spoken by Fadedja and Kenouz Nubians, respectively. Despite literature arguing for the proximities and similarities among these two dialects, It is challenging for a Fadidja Nubian to understand the flow of a Kenzi conversation and vice-versa.

There is a wealth of material in Nubian; however, it is often orally disseminated, with very little recorded. Nubian was the main medium for the expression of Nubian women, whose isolation in old Nubia exposed them to the Arabic language significantly less than their male counterparts, who often migrated to Arabic-speaking contexts for wage work in the first half of the twentieth century. This delay made Nubian literature, printed and distributed in Arabic, a space for male authors. Both oral and literary production of the Nubian culture after displacement contained vivid depictions of the lost land.

\subsection{Oral Narratives of Nubian Places}

Stories about the old land are a regular interaction in the life of Nubians growing up. The stories are charged with a pain and longing driven by the feeling of displacement in their village. The mixture of fantasization and complaint are a way to summon power in a situation of disposition. 'Our old village was a piece of paradise by the river [Nile]. There we had everything: vegetables, fruits, fish, 
and so many palm trees that you could not count. We did not need the [Egyptian] government to give us anything.' This nostalgic statement was a repeated one that my grandaunt Anna Zolikha said to me as I would stand next to her cracking house ${ }^{2}$. Stories of Nubian women were often spatial; they were often a commentary on the shortcomings of the state-built settlement.

Our palm tree died due to poor soil quality in the settlement. My grandmother, like many others, had tried several times to sustain it in the small courtyard of her dwelling unit. Planting a palm tree in the middle of the courtyard had been a tradition in Nubian architecture before displacement; it was an important mechanism in mitigating the high temperature inside the house. Every time we sat in that courtyard where her palm tree had died, my grandmother would start telling stories about how palm trees were lush and fruitful in the old land and how she had a great palm tree in the middle of the house. The images in everyday stories of Nubian women represent a nostalgic ecosystem in which there are lush trees, prosperous land, happy dogs, and colours. The stories were dynamic and elaborate and developed with the time and spatial needs of their makers.

Sand was the interim canvas for Nubians in the Tahgeer villages. When the story warranted a visualisation, Nubians would sit on the sandy floor of their settlement houses and draw using their index fingers or palm wickers. In the social context of the story, the narrator often drew icons, movement patterns between houses, or shapes of structural elements, all of which were maps that depicted the social space in the old land. Latour (2012) describes this practice as 'Savage Geography'. Latour evokes a story about an old man and a geographer in which the old man draws a map in the sand while the geographer draws the map on paper. When the tide comes, the map on the sand disappears while the one on the paper is preserved. In contrary to Latour's proposition, I believe that knowledge projected on the sand is documented in the collective memory in which these maps and images are deposited and reformed to produce a virtual map that is far from savagery.

\subsection{Projection of Nubia in Nubian Literature}

While oral narratives in our case are a venue to publish testimonies and descriptions and to assert the ethos of the old land, they are the first place of production. Other artistic venues, such as valorisable literature and visual arts, were available to a handful of Nubians, mostly Nubian men in urban centres, who could obtain a layer of privilege and successfully communicate a literary subject of Nubia through novels or paintings in which the nostalgic space manifests itself in a highly descriptive fashion. Authors who lived in the settlements, predominantly men and those who produced texts of fiction or historiographies about the old land, were too far from the dominant centre or the Egyptian mainstream to be visible, thus rendering their work as a single copy of handwritten notebooks in their houses. We find one or two of those authors in every village, each with a pile of notebooks in an old cupboard.

Idris Ali, Haggag Addoul, and Mohammad Khalil Qassem are some of the few known Nubian voices in Arabic literature. All their work is centred around the Nubian experience while depicting Nubian—and their own—pain, frustration, and longing for a Nubian land as recurrent. Ali (1998), for example, describes the state of the protagonist in his novel Dongola: A Nubian Story as follows: 'He felt a violent nostalgia for the sight of Nubia before its final immersion' (Ali 1998). In this excerpt, we can see the intense depiction of longing within the context of trying and failing to produce Nubian nationalism (DiMeo 2015). In the first Nubian novel in Arabic literature (Gilmore 2015), Al Shamandura, Qassem (1968) portrays a social-realist articulation of a Nubian society before, during, and after the heightening of the Aswan Low Dam.).

Nubian sense of loss is always present in Nubian literature. In these texts, lost and virtualised Nubian spaces find a fertile soil to inhabit. El Shamandora, for instance, contains an elaborate description of old Nubia - the trees, the sky, the vegetation, the atmosphere, and every single detail

2 Menna Agha's Field notes, Qustul, 29 December 2016. 
of a scene. It is as if the author wished for a retroactive audio-visual recorder but only had his pen. Qassem also expresses his feelings toward these landscapes; his words are not a neutral description but rather a confession of his feelings of loss and longing masked in what simply appears to be an author describing the context of his story. Nubians have always revered El Shamandura and basked in the spatialities it offered between its lines. However, the novel was criticised by non-Nubian readers for its excessive description, which they found did not add anything to their reading experience.

There is no material proof that the old land was that paradise in our stories, yet the space that lives in our collective imagination can be seen as the paradise we want as opposed to the one we once had. As no place is real or unreal in its entirety, all places start in reality, but once they enter the text, they settle in spatial illusion, in the unreal, the imaginary, and the virtual (Al Nossair 2015). What I strongly believe is that nostalgic space is 'real' and that the Nubia we imagine is true. This presents the Nubian nostalgic space as a venue for epistemic production, cultural production, and consequently spatial production-a space to promote the Nubia that matters to Nubians.

\section{Archaeology of 'the Now' Space}

As Nubians in displacement, whether in settlements or diaspora, we are raised to see and hear a lost utopia. If space, as Lukermann (1964) argues, is a way for us to understand the simple fact of reality, then Nubians have a dual-space reality. We live in the space of the imagined and the space of the actual. Between these spaces exists a contestation that keeps us displaced and drives us to materialise the immaterial and embody the disembodied according to an image of a land that is rendered in our imaginations-a layout of a Nubia, presumably the 'old land', that is virtually sculpted according to the detailed descriptions in our grandmothers' stories, a description that tries to territorialise the actual world.

Our nostalgic space, with its social organisations and images, becomes utilised in creating space elsewhere Harkening back to the trees from her mother's stories stories, my mother would describe our house to an incoming visitor, 'We are the house with the five lush palm trees', encouraging me to see a direct link between my grandmother's palm tree stories and the five palm trees my mother has in her garden in a Cairo suburb. My grandmother's story also has defined the behaviours around these palm trees; around them, we are reminded we are Nubian. The main struggle for Nubian nostalgic space, however, is neither about nostalgia or the question of its utility; it is about Affective justice, about having the right to feel pain, loss, and longing and the right to emote a space, make it, and live in it.

\subsection{Nubia Reincarnated in Displacement}

The image of old Nubia reincarnates in Nubian spatial production in the post-displacement sites. Nubians tended to develop their space in direct relation to that virtual ecosystem that lives in stories, songs, and novels, and they still call that virtual space home even though most Nubians nowadays did not witness the process of displacement nor have they seen their original land. Evidence of this incarnation can be seen in middle school children in art classes when Nubian children, including myself, try to fulfil the art class requirement of drawing rural scenes; we draw an old Nubian village, referenced directly from the landscapes that live in nostalgia. Spatial incarnations in material spaces are deemed to follow Nubians' redirected schemes, elements, and spatial compositions from old Nubian architecture within the process of spatial production in their settlements or elsewhere.

The typical resettlement village in what was named New Nubia had a modern linear grid and a linear orientation for residential buildings, with a concentration of building plots surrounded by agricultural land. The rectilinear grid was often dominated by the main automobile street, with services such as a mosque, commercial centre, school, sports centre, and post office in the heart of this area. The design was often referred to as unimaginative (Serageldin 1982; Ghabbour 1991) due to its pure form and the synthetic spaces that appropriated elements of Nubian architecture but failed to offer the spatial qualities resembling those of the original land. The first trials of reincarnations of 
the old land were in the early years of displacement. As Fernea and Kennedy (1966) note, the unique artistic and architectural tradition of Old Nubia is reasserting itself and being superimposed upon the drab uniformity of public housing.

Nubians have been-and still are-summoning elements and spatial compositions from the old land, one of which is the mastaba, a cuboidal bench often attached to the main facade in traditional Nubian architecture. Nubian women started to attach mastabas to their houses in the resettlement village (Hopkins and Mehanna 2011). Nubian mastabas were added to the front, and often only, facade in the settlement dwelling units. These exterior cuboidal benches acted as an extension of the state-built dwelling. The iconographic value of the object and its space-making capacities allowed the mastaba to foster a Nubian agency. Even though the trend of building these benches was initiated by Nubians who actively experienced them, younger generations maintain the reproduction of this element not only for its utility but also for its culture-making abilities (Agha and DeVos 2017). It is worth mentioning that the reincarnated mastaba was not a replica of its old versions but rather a repurposed nostalgic icon reproduced to mend the failures of the existing space, especially the failure of that space to perform a Nubian agency.

Ethnographic surveys, as well as spatial surveys, show the inadequacy of the state-built environment in fostering a Nubian life. Dwelling units especially did not act as houses; their design has caused the housing unit to be divorced from it political capacities'. For that reason, Nubians have developed a community house, a madyafa, that is a new typology replicating a traditional Nubian house, but in this case, the building acts as a community centre. It is a reproduction of Nubian residential architecture used to accommodate the political/social/economic activities and to be shared among a group of people. It is also a tool for the spatial preservation of Nubian social life and a singular agent that resembles the Nubian architecture that lives in nostalgia among a modernistically built environment. The madyafa is an ideal example of the innovation capacities in the imagined territory, as it was not a part of the traditional Nubian architecture, yet it is a rendition produced by the spatial needs and aspirations formulating the nostalgic territory.

\subsection{Nubian Reincarnations in the Diaspora}

While the state-built settlements lacked the sufficient resources and infrastructure to support the new generations of Nubians, by the 1980s and 1990s, newly formed families, just like my own, moved to Egyptian cities and the Arab Gulf in pursuit of economic resources. In their material geographic diaspora, Nubians maintain their dual spatial existence. They still live in the collectively imagined old land and maintain their belonging to their original villages through a networked system. Nubian networks' main nodes are called associations and clubs in Cairo and Alexandria; they carry names of original villages, and people from that village are paying subscribers. The collective governing body is the General Nubian Club in Cairo, where they rotate power between Nubian groups. Social relations connect associations to settlements in Tahgeer and Nubian associations outside Egypt, especially in the Arab Gulf, which is the major source of Nubians' economic power.

Nubian families in Egyptian urban centres, like mine, for instance, are linked to their villages through an association that carries the name of that Nubian village (in my case, the association of Qustul). These associations in Cairo and Alexandria are permanent hubs for Nubians such as my family to keep traditions and stay linked to their village. The Qustul association in Cairo consists of two residential apartments in a poor neighbourhood of Abdeen. Volunteer members took down the wall between the apartment to make space for meals that include thirty-five to fifty people, but they also made sure the space is able to accommodate projectors for their annual presentation in which students from Qustul, myself included, are celebrated every year for their achievements.

The making of these spaces unveils the emotional basis of their link to a lost village, and these spaces are the main pillars of the Nubians' network. Nubians in diaspora and displacement villages continually attempt to build a piece of Nubia; these spaces do not look like the archived images of the old land but rather like the evolution of the land, had it stayed, and its own people had developed it. 
Therefore, I argue that the land remained in the nostalgic space. Moreover, I argue that the landscapes were able to export themselves as a developed version in accordance with or in resistance to external factors. Such phenomena show that Nubian spaces have continued developing to maintain a Nubian peoplehood; they made use of the cracks in the material spatial systems and carved a space with their agency. Along with this process of development functions with a sense of loss as this space's main foundation, an urge to continue making spaces for what is Nubian continues. All the spaces I have detected within the mapping are either a mimic, a representation, or a succession to a feature of the built environment of the old land.

\section{Theorising Nubian Territory and Territoriality: Nostalgia as Emotional Labour}

In the case of Nubian's and their nostalgia, a clear distinction can be made between nostalgic narrative and nostalgic metanarratives. I find that a nostalgic metanarrative generates a foundation for common virtual space, as it is uncontested and pervasive in the Nubian collective conscious; the metanarrative, thus, is the virtual landscape of the imagined Nubia. Nostalgic Nubian narratives, however, offer spatial projections, dynamic constellations, and fluctuating images stemming from memories. Micronarratives in forms of nostalgic microhistories populate the landscape and morph it. As these stories are altered through time, the space is altered as well, rendering a constant state of fluctuation.

The disembodied Territory of Nubians is constructed due to a Nostalgic metanarrative, a grand totalising cultural narrative schema which orders and explains knowledge and experience (Stephens and McCallum 1998). In my opinion, the existence of a Nubian territory is credited to a pervasive metanarrative, a grand collective perception of a constructed reality. It is the uncontested story of the paradise-like old land. Poststructuralist theorists like Foucault and Lyotard exhibited aversion towards metanarratives, as they are often created to reinforce a power structure (Lyotard 1984). In this case, a metanarrative is used to acquire power for disenfranchised peoplehood; it could be seen as a grand counter-narrative. Although I tend to agree with Foucault's and Lyotard's position, I find a nostalgic metanarrative to be a great asset and space-making apparatus in the case of Nubians.

An objective analysis could certainly challenge such a metanarrative; historical evidence shows that Nubians were in dire circumstances in 1902, when the Egyptian (then) Kingdom started implementing hydraulic projects on the Nile. Nubians lost large areas of their arable land, which drove their society into an institutionalised migration as the male population left to seek wage labour in urban centres (Hale 1989). Nevertheless, older generations-all of whom were born after 1902—who witnessed the old land insist that it was a paradise. Despite the implied notion, the perpetuation of nostalgic images of Nubia is not concerned with historical accuracy, as nostalgia becomes a space of fabrication and selective preservation (Mazrui 2013). In its forging of truth, I find a design process and-as I argue - a space of production.

I find the concept of 'territory' useful in understanding such spatial phenomena, especially when territory is studied according to geographer Claude Raffestin's original paper 'Space, Territory, and Territoriality' (Raffestin 2012). To Raffestin, a territory is derived 'from the activity that humans carry out in the space that is given or provided to them in common' and 'from space ... qua production by the projection of labour'. According to the Swiss geographer, the difference between a space and a territory is labour, as space becomes a territory through production. Accordingly, I argue that Nubia is a virtual territory to contemporary Nubians. The collective virtual spatiality is transformed through emotional labour into a disembodied territory, using nostalgia as its means of production. This renders the preservation and perpetuation of Nubia as a disembodied territory, be it in a virtual space or a material one, crucial to maintaining the production of a Nubian identity.

'Territory' is often studied in the context of and associated with nationalism, an association that urban sociologist Saskia Sassen aims to dissolve. She understands territory 'as a complex capability with an embedded logic of power/empowerment and of claim-making' (Sassen 2013). Sassen's understanding of territory allows us to see Nubian nostalgic disembodied territories as a resource for 
community building. Her understanding also allows for a conceptualisation that avoids falling into a futile nationalist sentiment. Nationalism has proved its inability to serve displaced Nubians, who have failed in their attempts to forge their own nationalist space, as DiMeo (2015) concludes in his remarkable reading of Dongola: A Nubian Novel. Nostalgia, however, has formed a different kind of territory, one that has served Nubians and their community-making efforts.

If what Nubians created in the nostalgic space is a territory, then nostalgia can be seen as a means of territoriality. According to Raffestin (2012), 'The construction of territory is the consequence of territoriality defined as the ensemble of relations that society maintains with exteriority and alterity for the satisfaction of its needs.' The Nubian-imagined territory, as conceptualised in this paper, is the only Nubia that remains, and it is a rare space of Nubian agency. Nubians grow to join this territory through a nostalgic initiation, by learning that there is a territory that is ours-not one we can touch, but a paradise-like old land that is ours, unlike the state-built settlement that is not.

Understanding the relationship between the material space surrounding Nubians and the space of their disembodied territory can benefit from contemporary research on virtual spaces. Castronova (2008) offers an understanding of the relation between virtual spaces and the material world in his book Synthetic Worlds. Castronova investigates the behaviour of players in online virtual worlds, and he finds that these virtual spaces are a 'porous membrane'. He claims that there is a two-way movement of the player between the material and the virtual space, this porousness allows the players to step in and out. Similar to virtual online spaces, contemporary Nubians move between the two spaces and move features from one to the other, especially the noted reincarnations of elements and spatial constitutions from their imaginaries to their material space.

Then, the nostalgic space can be conceptualised as a territory disembodied in its materiality and virtual in its dimension-a territory produced and maintained through emotional labour, in this case, nostalgia. The territory has interesting spatial characteristics. It contains a shared vision as well as a fluctuating layout and their belonging is not contingent on their geographic proximity to the territory'. Besides, it allows its occupants to live simultaneously in multiple spaces; it allows them to move between and acknowledge both the imagined and the material as lived spaces. Through this acknowledgement, the virtual territory is able to inflict change on the material world.

Territorial performance of Nubians, as an example of landless peoplehood, depicts such phenomena of disembodied territories as an opportunity to understand placemaking and territory making in a different light. The disembodied imagination of 'Nubia' allows the concept to transcend the spatial limitation of the displacement site, and its emotional surplus is translated into a territorial performance. Territoriality, in this case, precedes the existence of the territory, one in which Nubians recreate a Nubia that they have never seen. Disembodied territorialities can create a disruptive entity by utilising a networked structure and avoiding conflict over spatial resources, as they become able to reincarnate these spaces regardless of geographical restraints.

\section{Conclusions}

Nostalgia has been the topic of contestation in academic realms, with researchers suggesting that giving 'ourselves up to longing for a different time or place, no matter how admirable its qualities, is always to run the risk of constricting our ability to act in the present' (Atia and Davies 2010). The tangible added value of nostalgia detected in this research, however, suggests otherwise. Said (2000) teaches us that 'the interplay among memory, place, and invention can do if it is not to be used for the purposes of exclusion, that is if it is to be used for liberation and coexistence between societies whose adjacency requires a tolerable form of sustained reconciliation'. The collective memory of loss is not innate or passive. On the contrary, it is a place of reconstruction, a tool through which displaced and dispossessed peoplehoods can creatively use nostalgia, and it 'forms of temporal belonging to create a sense of a continuous self' (May 2017).

As the Nubian land was submerged in its materiality due to the building of the Aswan High Dam in the 1960s, the term Nubia now is defined through nostalgic apparatus. Nevertheless, the term 
has come to mean different things, as different nostalgic apparatuses have stemmed from different political interests. To post-displacement Nubians, nostalgia is the mechanism of creating a virtual space of Nubian agency. In displacement, Nubians have evoked a nostalgic metanarrative of the 'lost paradise' to create a common space. This metanarrative has been acting as the ground foundation for common space, and this common space has been populated and modelled using stories and images of our old land.

Such nostalgic production can be conceptualised as a territory in the light of Raffestin's (2012) definition of space. Raffestin poses territories as a result of production through labour in a given or acquired space. Correspondingly, on the one hand, I can understand the virtual space generated through a metanarrative in the Nubian collective conscious to be an acquired space, and on the other hand, I find micronarratives and their production through affective resources to be emotional labour. Nostalgia, in this case, is a mode of territoriality, as it fuels the making of a territory. Moreover, the territory becomes a space of production rather than a space of preservation, as it is morphed by the space of the now rather than the space it claims to preserve, making it a tool for space making.

Such phenomena make it possible for this research to argue for the utility of nostalgia in this case, as it is used to procure a dispossessed power-space making. Such spatial production enables me, a third generation displaced Nubian, to argue that Nubia still exists. In conclusion, nostalgia, for the dispossessed, is often put to work. It is never an idle act of remembrance but rather a means of production to those who need to retrieve a value. Nostalgia in its falsification of documented realities about spaces and places is not deceiving; it produces the 'other' space.

Funding: This research was supported by University of Antwerp Research Fund (DOCPRO1 BOF).

Acknowledgments: The author acknowledges the efforts of Els De Vos in acquiring funds for this project, and than her for relentless efforts to advise, promote and support this project. I would like to especially thank her for reading and commenting on this paper, which was integral for its development.

Conflicts of Interest: The author declares no conflict of interest. The funders had no role in the design of the study; in the collection, analyses, or interpretation of data; in the writing of the manuscript, or in the decision to publish the results.

\section{References}

Abushouk, Ahmed Ibrahim. 2010. The Anglo-Egyptian Sudan: From Collaboration Mechanism to Party Politics, 1898-1956. The Journal of Imperial and Commonwealth History 38: 207-36. [CrossRef]

Agha, Menna, and Els DeVos. 2017. Liminal Publics, Marginal Resistance. Journal of a the Interior Design/Interior Architecture Educators Association, 88-101. Available online: http://idea-edu.com/journal/index.php/home/ article/view/12 (accessed on 31 January 2019).

Al Nossair, Yassin. 2015. An Introduction to Spatial Critique. Damascus: Ninawa Publishing House.

Ali, Idris. 1998. Dongola: A Novel of Nubia. Fayetteville: University of Arkansas Press.

Arkell, Anthony John. 1961. A History of the Sudan from the Earliest Times to 1821, 2nd ed. London: University of London, The Athlone Press.

Atia, Nadia, and Jeremy Davies. 2010. Nostalgia and the Shapes of History: Editorial. Memory Studies 3: 181-86. [CrossRef]

Bechhaus-Gerst, Marianne. 2011. The (Hi)Story of Nobiin-1000 Years of Language Change. Bern: Peter Lang.

Bell, Herman. 2009. Paradise Lost: Nubia before the 1964 Exodus. Khartoum: DAL Group, vol. 1.

Boym, Svetlana. 2008. The Future of Nostalgia. New York: Basic Books.

Castronova, Edward. 2008. Synthetic Worlds: The Business and Culture of Online Games. Chicago: University of Chicago Press.

Cernea, Michael M. 1996. Public Policy Responses to Development-Induced Population Displacements. Economic and Political Weekly 31: 1515-23.

Dafalla, Hassan. 1975. The Nubian Exodus. Nordiska Afrikainstitutet. London: C. Hurst \& Co.

DiMeo, David. 2015. Unimaginable Community: The Failure of Nubian Nationalism in Idris Ali's Dongola. Research in African Literatures 46: 72. [CrossRef]

Duncan, Rachuonyo. 2013. Nubians in Kenya: A People Denied. Think Africa Press (Blog), February 22. 
Emery, Walter Bryan. 1967. Lost Land Emerging. New York: Scribner.

Fernea, Robert A. 1963. The Ethnological Survey of Egyptian Nubia. Current Anthropology 4: 122-23. [CrossRef] Fernea, Robert A., and John G. Kennedy. 1966. Initial Adaptations to Resettlement: A New Life for Egyptian Nubians. Current Anthropology 7: 349-54. [CrossRef]

Ghabbour, Samir I. 1991. Involuntary Resettlement in Development Projects: Policy Guidelines in World Bank-Financed Projects, by Michael M. Cernea: 1988. Environmental Conservation 18: 91-92. [CrossRef]

Gilmore, Christine. 2015. 'A Minor Literature in a Major Voice': Narrating Nubian Identity in Contemporary

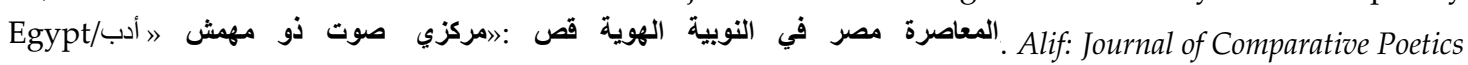
35: 52-74.

Gregory, Derek. 2001. Colonial Nostalgia and Cultures of Travel: Spaces of Constructed Visibility in Egypt. In Consuming Tradition, Manufacturing Heritage: Global Norms and Urban Forms in the Age of Tourism. Abingdon: Routledge, pp. 111-51.

Hale, Sondra. 1989. The Impact of Immigration on Women: The Sudanese Nubian Case. Women's Studies 17: 53-56. [CrossRef]

Haraway, Donna. 1988. Situated Knowledges: The Science Question in Feminism and the Privilege of Partial Perspective. Feminist Studies 14: 575-99. [CrossRef]

Harding, Sandra G. 2004. The Feminist Standpoint Theory Reader: Intellectual and Political Controversies. Hove: Psychology Press.

Hassan, Fekri A. 2007. The Aswan High Dam and the International Rescue Nubia Campaign. African Archaeological Review 24: 73-94. [CrossRef]

Hillelson, Sigmar. 1930. Nubian Origins. Sudan Notes and Records 13: 137-48.

Hopkins, Nicholas S., and Sohair R. Mehanna. 2011. Nubian Encounters: The Story of the Nubian Ethnological Survey 1961 to 1964. Cairo: American University in Cairo Press.

Horton, Alan W. 1964. The Egyptian Nubians. The American Universities Field Staff Reports Service, Northwest Series XI: 283-302.

Hui, Allison. 2013. Placing Nostalgia: The Process of Returning and Remaking Home. Waterloo: Wilfrid Laurier University Press.

Janmyr, Maja. 2016. Nubians in Contemporary Egypt: Mobilizing Return to Ancestral Lands. Middle East Critique 25: 127-46. [CrossRef]

Kirwan, Lawrence P. 1974. Nubia and Nubian Origins. Geographical Journal 140: 43-51. [CrossRef]

Latour, Bruno. 2012. Visualisation and Cognition: Drawing Things Together. Avant: Trends in Interdisciplinary Studies 3: 207-60.

Lukermann, F. 1964. Geography as a Formal Intelectual Discipline and the Way in Which It Contributes to Human Knowledge. The Canadian Geographer/Le Géographe Canadien 8: 167-72. [CrossRef]

Lyotard, Jean-François. 1984. La Condition Postmoderne: Rapport Sur Le Savoir. Manchester: Manchester University Press.

May, Vanessa. 2017. Belonging from Afar: Nostalgia, Time and Memory. The Sociological Review 65: 401-15. [CrossRef]

Mazrui, Ali A. 2005. The Re-Invention of Africa: Edward Said, V. Y. Mudimbe, and Beyond. Research in African Literatures 36: 68-82. [CrossRef]

Mazrui, Ali A. 2013. Cultural Amnesia, Cultural Nostalgia and False Memory: Africa's Identity Crisis Revisited. African and Asian Studies 12: 13-29. [CrossRef]

Merriam, Sharan B., Juanita Johnson-Bailey, Ming-Yeh Lee, Youngwha Kee, Gabo Ntseane, and Mazanah Muhamad. 2001. Power and Positionality: Negotiating Insider/Outsider Status within and across Cultures. International Journal of Lifelong Education 20: 405-16. [CrossRef]

Nasser, Gamal Abdel. 1960. President Gamal Abdel Nasser Words to Nubians. Speech, Aswan, January 11.

Pini, Barbara. 2004. On Being a Nice Country Girl and an Academic Feminist: Using Reflexivity in Rural Social Research. Journal of Rural Studies 20: 169-79. [CrossRef]

Qassem, Mohammad Khalil. 1968. Al-Shamandura. Cairo: Hay'a al-'Amma li-Qusur al-Thaqafa.

Raffestin, Claude. 2012. Space, Territory, and Territoriality. Translated by Samuel A. Butler. Environment and Planning D: Society and Space 30: 121-41. [CrossRef]

Said, Edward W. 2000. Invention, Memory, and Place. Critical Inquiry 26: 175-92. 
Sassen, Saskia. 2013. When Territory Deborders Territoriality. Territory, Politics, Governance 1: 21-45. [CrossRef] Scudder, Thayer. 2016. Aswan High Dam Resettlement of Egyptian Nubians. In Aswan High Dam Resettlement of Egyptian Nubians. Berlin: Springer, pp. 1-52.

Serageldin, Mona. 1982. Planning for New Nubia 1960-1980. In The Changing Rural Habitat; Volume I: Case Studies. Singapore: Concept Media/Aga Khan Award for Architecture.

Stephens, John, and Robyn McCallum. 1998. Retelling Stories, Framing Culture: Traditional Story and Metanarratives in Children's Literature. New York and London: Garland Publishers.

Waterbury, John. 1979. Hydropolitics of the Nile Valley. Syracuse: Syracuse University Press.

(C) 2019 by the author. Licensee MDPI, Basel, Switzerland. This article is an open access article distributed under the terms and conditions of the Creative Commons Attribution (CC BY) license (http://creativecommons.org/licenses/by/4.0/). 